what is evidence?

monument, exhibition, memory

rationalism and emotion
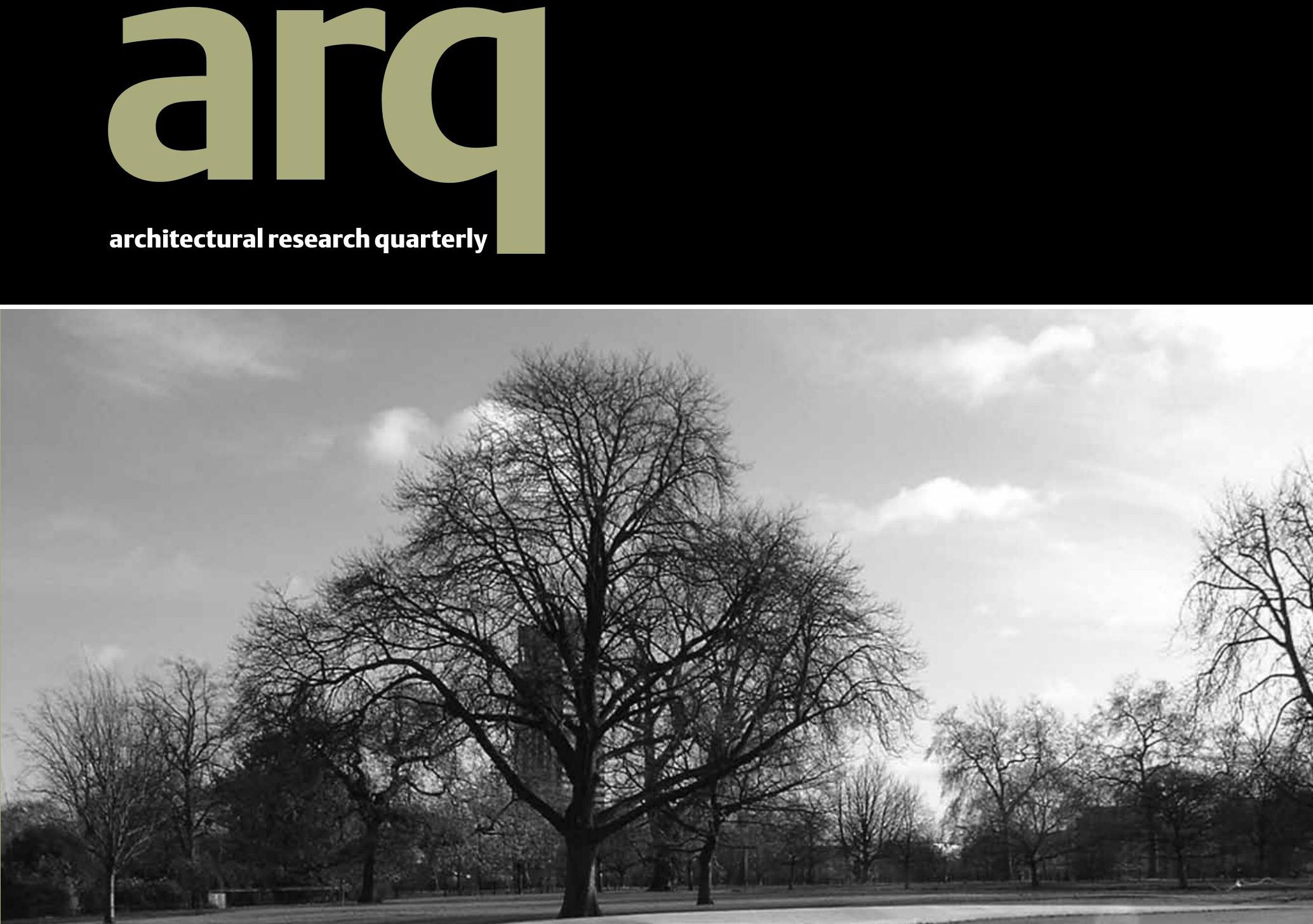


\section{Richard Weston}

E westonr1@cardiff.ac.uk

Adam Sharr

E sharr@cardiff.ac.uk

The Welsh School of Architecture

Cardiff University

Bute Building

King Edward VII Avenue

Cardiff, CF10 3NB, UK

$\mathrm{T}+44(29) 20874431$

$\mathrm{F}+44(29) 20874926$

Wayne Forster

E forsterw@cardiff.ac.uk

Julie Gwilliam

E gwilliamja@cardiff.ac.uk

Stephen Kite

E kites@cardiff.ac.uk

Juliet Odgers

E odgersj@cardiff.ac.uk

$\begin{array}{ll}\text { Associate Editor } & \text { Charles Rattray } \\ \text { Reviews + Insight } & \text { School of Architecture } \\ & \text { University of Dundee } \\ & \text { Perth Road } \\ & \text { Dundee } \\ & \text { dh1 } 4 \text { hu } \\ & \mathrm{T}+44(0) 1382345231 \\ & \mathrm{~F}+44(0) 1382203631 \\ & \text { E c.rattray@dundee.ac.uk } \\ & \\ \text { Editorial Assistants } & \text { Samuel Austin } \\ & \begin{array}{l}\text { Edward Wainwright } \\ \text { E arq@cardiff.ac.uk }\end{array} \\ & \text { Angela Ashton } \\ \text { Art Editor+Design } & \text { E design@angelaashton.co.uk }\end{array}$

Thomas Fisher University of Minnesota, Minneapolis, USA

Tony Fretton Tony Fretton Architects, London, UK

Elizabeth Hatz KTH Arkitekturskolan, Stockholm, Sweden

Louisa Hutton Sauerbruch Hutton Architects, Berlin, Germany

Mari Hvattum Oslo School of Architecture and Design, Norway

David Leatherbarrow University of Pennsylvania, Philadelphia, USA

Hannah Le Roux University of the Witwatersrand, Johannesburg, South Africa

Tarla MacGabhann MacGabhann Architects, Letterkenny, Republic of Ireland

Mary McLeod University of Columbia, New York, USA

Simo Paavilainen Helsinki University of Technology, Finland

Alan Powers University of Greenwich, London, UK

Mohamed Sharif Koning Eizenberg Architecture, Santa Monica, CA, USA

Simon Allford Allford Hall Monaghan Morris, London, UK

Andrew Ballantyne University of Newcastle, UK

Peter Blundell Jones University of Sheffield, uK

Peter Carolin University of Cambridge, UK

Richard Coyne University of Edinburgh, UK

Brian Ford University of Nottingham, UK

David Jenkins Foster and Partners, London, UK

Niall McLaughlin Niall McLaughlin Architects, London, UK

Jane Rendell Bartlett School of Architecture, UCL, London, UK

Jonathan Sergison Sergison Bates Architects, London, UK

Koen Steemers University of Cambridge, UK

Robert Tavernor London School of Economics, UK

Jane Wernick Jane Wernick Associates, London, UK

lain Boyd Whyte University of Edinburgh, UK

arq: Architectural Research Quarterly (issn 1359-1355) is published four times a year in March, June, September and December. Four parts form a volume. The subscription price which includes print and electronic access (but excluding vat) of volume 14 is $£ 193.00$ (US $\$ 320.00$ in USA, Canada and Mexico) for institutions; $£ 43.00$

(US $\$ 66.00$ in USA, Canada and Mexico) for individuals and $£_{31.00}$ (US $\$ 52.00$ in USA, Canada and Mexico) for students, which includes print only, ordering direct from the publishers and certifying that the journal is for their personal use. Single parts are $£ 51.00$ net (US $\$ 82.00$ in USA, Canada and Mexico) plus postage. EU subscribers (outside the UK) who are not registered for vat should add vat at their country's rate. vat registered members should provide their vat registration number. Japanese prices for institutions (including ASP delivery) are available from Kinokuniya Company Ltd, P.O.

Box 55, Chitose, Tokyo 156, Japan. Orders which must be accompanied by payment, may be sent to a bookseller, subscription agent or direct to the publisher: Cambridge University Press,

The Edinburgh Building, Shaftesbury Road,

Cambridge CB2 8RU; or in the USA, Canada and Mexico: Cambridge University Press, Journals

Fulfillment Department, 100 Brook Hill Drive,

West Nyack, NY 10994-2133. Copies of the journal for subscribers in the USA, Canada and Mexico are sent by air to New York to arrive with minimum delay.

\section{Copying}

The journal is registered with the Copyright Clearance Center, 222 Rosewood Drive, Danvers, MA 01923, USA. Organizations in the USA who are also registered with C.C.C may therefore copy material (beyond the limits permitted by sections 107 and 108 of U.S. Copyright law) subject to payment to C.C.C. of the per-copy fee of $\$ 16$. This consent does not extend to multiple copying for promotional or commercial purposes. Code 1359-1355/2010/\$16.

ISI Tear Sheet Service, 3501 Market Street, Philadelphia, PA 19104, USA, is authorized to s upply single copies of separate articles for private use only.

Organizations authorized by the Copyright Licensing Agency may also copy material subject to the usual conditions.

For all other use, permission should be sought from Cambridge or from the American Branch of Cambridge University Press.

Information on arq: Architectural Research Quarterly and all other Cambridge journals can be accessed via http://www.journals.cambridge.org/

This journal issue has been printed on FSC-certified paper and cover board. FSC is an independent, non-governmental, not-for-profit organization established to promote the responsible management of the world's forests. Please see www.fsc.org for information.

(c) Cambridge University Press 2010

Printed in the United Kingdom at the University Press, Cambridge 